\title{
JNS History and advances in spinal neurosurgery
}

\author{
JNSPG 75th Anniversary Invited Review Article \\ Corey T. Walker, MD, U. Kumar Kakarla, MD, Steve W. Chang, MD, and Volker K. H. Sonntag, MD \\ Department of Neurosurgery, Barrow Neurological Institute, St. Joseph's Hospital and Medical Center, Phoenix, Arizona
}

Insight into the historic contributions made to modern-day spine surgery provides context for understanding the monumental accomplishments comprising current techniques, technology, and clinical success. Only during the last century did surgical growth occur in the treatment of spinal disorders. With that growth came a renaissance of innovation, particularly with the evolution of spinal instrumentation and fixation techniques. In this article, the authors capture some of the key milestones that have led to the field of spine surgery today, with an emphasis on the historical advances related to instrumentation, navigation, minimally invasive surgery, robotics, and neurosurgical training.

https://thejns.org/doi/abs/10.3171/2019.9.SPINE181362

KEYWORDS fixation; fusion; history; innovation; instrumentation; navigation; plates; rods; robotics; screws; surgical technique

$\mathrm{B}$ EFORE spinal fixation techniques were developed in the early 20 th century, the treatment of unstable lesions centered on immobilization using bed rest, traction, splinting, and bracing. Surgical morbidity related to an absence of antiseptic technique, lack of thermocautery, and lack of appropriate anesthesia made nonsurgical treatments favorable. Early traction and immobilization racks, which date back to Hippocrates around $400 \mathrm{BCE},{ }^{51}$ were the mainstay of treatment until the 20th century. Despite little development in spine surgery techniques over the centuries, anatomical knowledge and an understanding of pathophysiology continued to grow. ${ }^{29}$ After the contributions of Semmelweis and Lister toward antisepsis in the operating theater at the end of the 19th century, spine surgery attempts resurged with much greater success. This resurgence included the first laminectomies performed by Macewen in $1886,{ }^{48}$ spinal tumor resection performed by Horsley in $1887,{ }^{74}$ and anterior column debridement for spinal cord decompression of tuberculous spondylitis through an anterolateral extrapleural approach performed by Ménard in 1895.53

In this historical review, we highlight some of the contributions to modern spine surgery with an emphasis on the development of spinal instrumentation and associated techniques that followed these great accomplishments (Fig. 1). While many of the great strides in the field are described here, hundreds of small contributions in each area helped to drive the field forward and cannot be captured in a single review. We hope to outline the enormous strides that have been realized in this relatively short period, so we can appreciate the many accomplishments that enable us to provide high-quality spinal treatments today.

\section{Thoracolumbar Fixation}

One of the earliest successful internal fixation techniques was developed by Hadra, who sought to stabilize cervical fractures caused by Pott's disease. ${ }^{33}$ In 1891, Hadra treated a cervical fracture by fastening a silver wire loop around the spinous processes in a figure-eight formation. Further development by Hadra and Lang improved these wiring techniques and laid the groundwork for internal stabilization, which improved recovery times and outcomes compared to those with external immobilization alone. This technique was independently advanced by Albee $^{2}$ and Hibbs ${ }^{40}$ in 1911 with the introduction of early posterolateral arthrodesis. Hibbs's technique, which ultimately became the predominant method of fusion for the subsequent 5 decades, involved using decorticated spinous process autografts folded downward to contact the caudal process while simultaneously decorticating the articular surfaces, resulting in interlaminar fusion. In 1923, autopsies performed on 9 persons who had received a Hibbs fusion before death revealed solid fusions, thereby verifying the successful, lasting nature of the procedure. ${ }^{8}$

Wiring techniques remained the mainstay of posterior

ABBREVIATIONS ACP = anterior cervical plating; $C T=$ computed tomography; FDA = US Food and Drug Administration.

SUBMITTED August 5, 2019. ACCEPTED September 3, 2019.

INCLUDE WHEN CITING DOI: 10.3171/2019.9.SPINE181362. 
Walker et al.

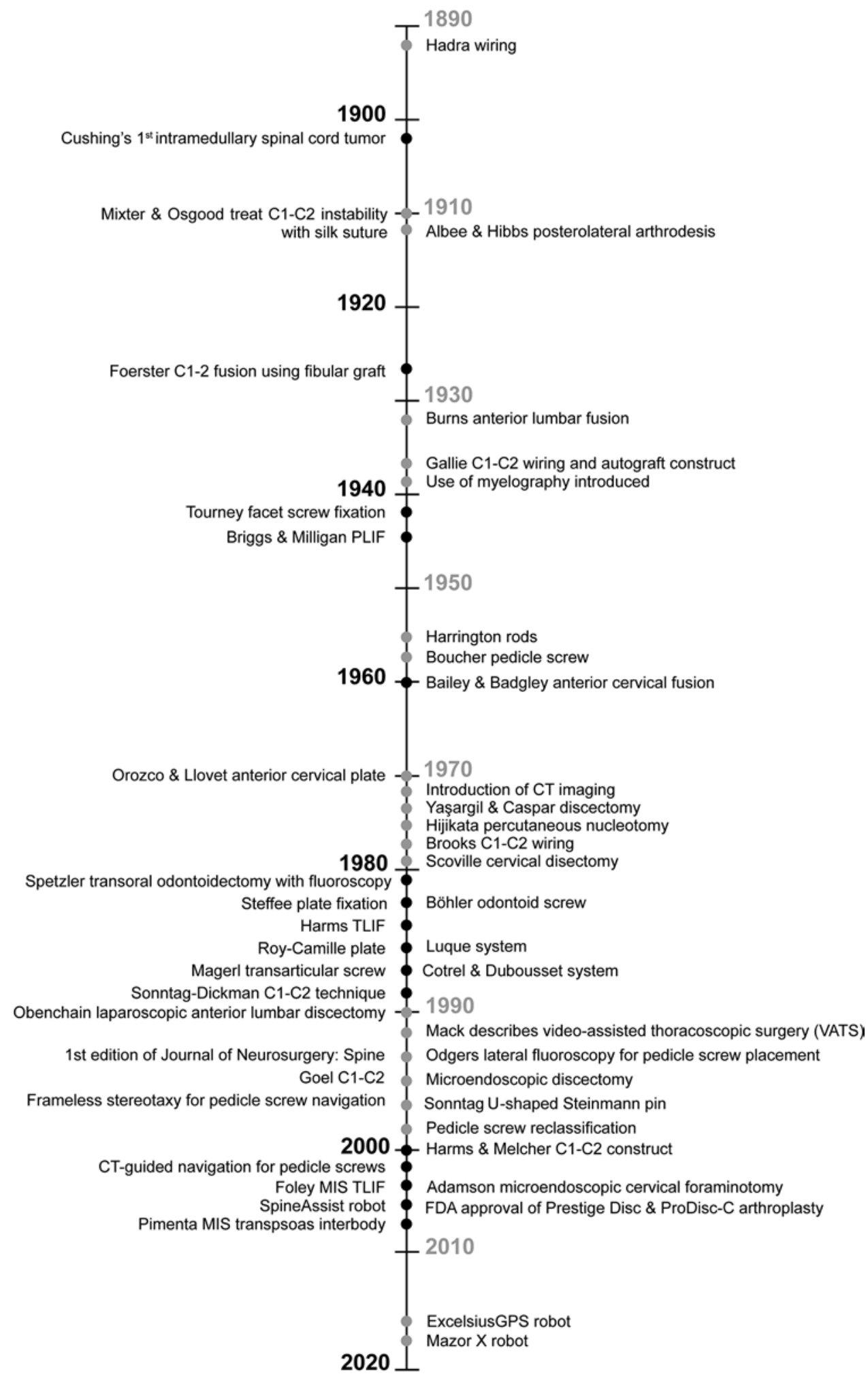

FIG. 1. Timeline highlighting major historical contributions to the field of spine surgery. MIS = minimally invasive surgery; PLIF = posterior lumbar interbody fusion; TLIF = transforaminal interbody fusion. 
A

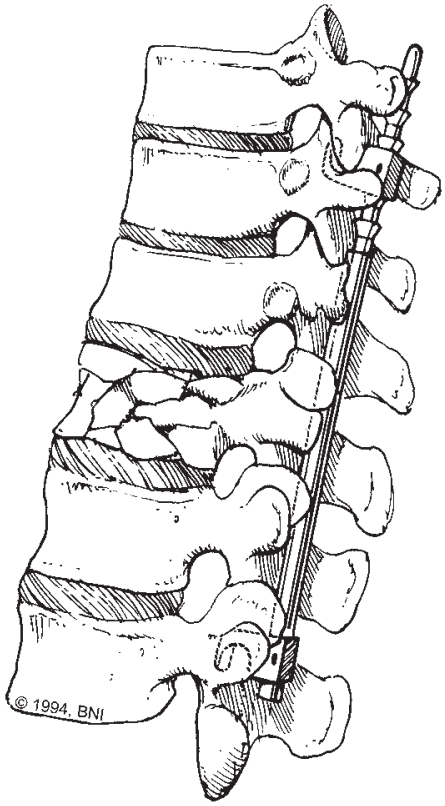

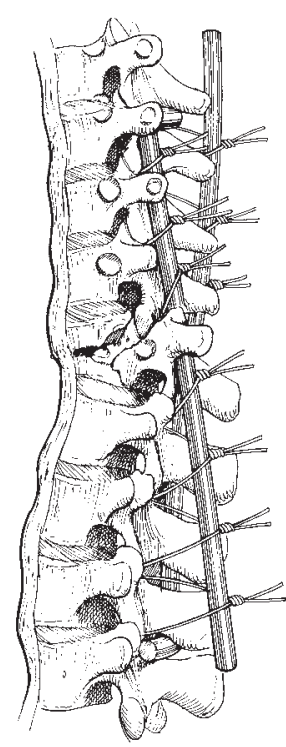

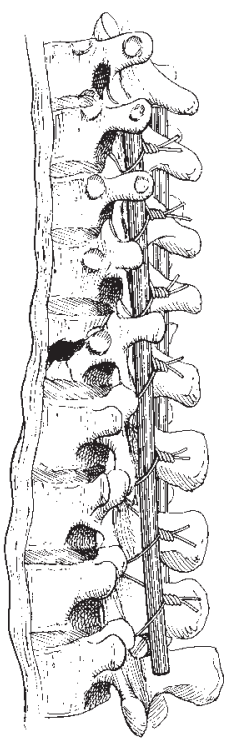

B

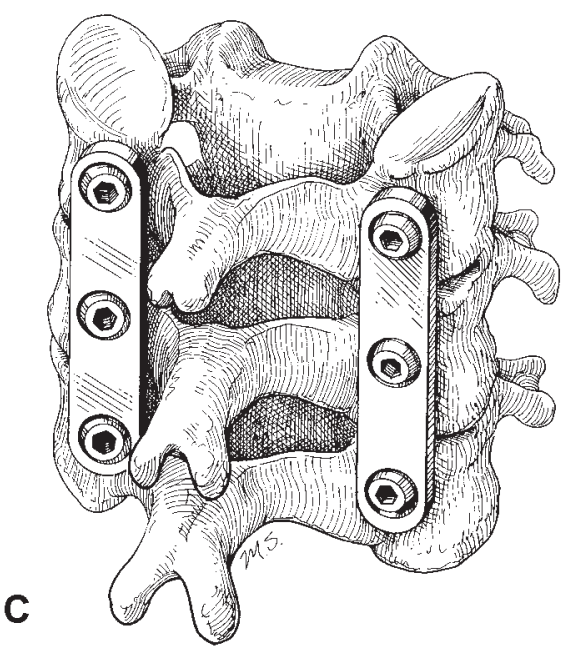

FIG. 2. Illustrations of major contributory fixation technologies: Harrington ${ }^{37}$ rod system $(\mathbf{A})$, Luque ${ }^{47}$ system for the thoracolumbar spine (B), and lateral mass plating system originally described by Roy-Camille (C). ${ }^{62}$ Figures $2 \mathrm{~A}-\mathrm{C}$ are used with permission from Barrow Neurological Institute, Phoenix, Arizona. Figure 2A previously appeared in Maric Z, Dickman CA: Instrumentation for posterior fixation of the thoracic and lumbar spine. BNI Quarterly 10:18-26, 1994. Figure 2B previously appeared in Vardiman AB, Sonntag VKH, Dickman CA: Thoracic spine instrumentation. Techniques in Neurosurgery 1:240-256, 1996. Figure 2C previously appeared in Dickman CA, Sonntag VKH, Marcotte PJ: Techniques of screw fixation of the cervical spine. BNI Quarterly 8:9-26, 1992.

spinal fixation for many years. In 1943, Tourney ${ }^{76}$ first described a technique of adding facet screws to the fusion construct to hasten recovery and obviate the need for longterm bracing, casting, and immobilization. This technique was modified and expanded by King, ${ }^{46}$ who presented his work in 1948. Importantly, these pioneers astutely realized that fixation did not replace the need for fusion and that arthrodesis remained the most important portion of the procedure. This focus propelled the first investigations into interbody arthrodesis with the introduction of posterior lumbar interbody placement by Briggs and Milligan in $1944 .^{12}$

In the late 1950 s, challenged by the need to treat neu- romuscular scoliosis (specifically paralytic scoliosis from poliomyelitis), Harrington ${ }^{37}$ designed a spinal instrumentation system using steel rods attached to hooks to correct the deformity through compression and distraction. Over the course of the next decade, he made iterative improvements to the system, and its applications expanded to include other types of scoliosis as well as stabilization for spinal trauma and other etiologies (Fig. 2). ${ }^{37,38,47,62} \mathrm{Im}-$ portantly, Boucher ${ }^{11}$ was credited with placing the first pedicle screw in 1959, with Harrington and Tullos ${ }^{39}$ later improving upon the technique, which had previously been thought to be too dangerous.

The rapid evolution of posterior instrumentation of the 
thoracolumbar spine then ensued (Fig. 2). Magerl ${ }^{50}$ and Dick and colleagues ${ }^{22,23}$ each made advances with fixation systems intended to improve biomechanical purchase and reduce the number of healthy segments needed for fusion constructs. ${ }^{83}$ In 1982, Steffee ${ }^{73}$ began designing a segmental spine plate fixation system, which brought with it the first notion of variable screw placement. In addition to these major design improvements in fixation systems, two major long-segment systems were developed to improve upon Harrington's system (Fig. 2A). In 1986, Luque ${ }^{47}$ introduced his wire-and-rod fixation system, which was intended to be a posterior fixation that better maintained sagittal contouring (Fig. 2B). Likewise, in 1987, Cotrel and Dubousset ${ }^{20}$ designed a pedicular fixation system that used bent rods that followed the natural curvature of the spine. These rods could attach to vertebral hooks or pedicle screws and could be used for scoliosis correction and universally for other applications. Despite the significant shortcomings of both of these systems, spinal deformity correction continued to improve and pushed forward innovations yielding successive iterative enhancements.

However, the growth of spinal instrumentation hit an impasse in the 1990s when multiple class-action lawsuits were brought against manufacturers, surgeons, and the governing societies (the American Association of Neurological Surgeons, the North American Spine Society, and the American Academy of Orthopaedic Surgeons) for the use of pedicle screws. These lawsuits came after the US Food and Drug Administration (FDA) asked manufacturers to stop the promotion of bone screws as pedicle screws because of the limited amount of data regarding their efficacy. An outcry from the media resulted, and the industry of spinal implants was criminalized, along with the surgeons placing the screws. A historical cohort study of pedicle screw fixation in thoracic, lumbar, and sacral spinal fusion ${ }^{82}$ was soon performed by both orthopedic and neurological surgeons from the defending societies, which showed that the use of pedicle screws improved fusion rates in degenerative spondylolisthesis from $70 \%$ to $90 \%$. Nevertheless, only after an enormous amount of debating and discussion from both the companies and surgeons did the FDA Advisory Panel on Orthopaedic and Rehabilitative Devices recommend to the FDA that the implants be changed from class III to class II. Still, no action was forthcoming. It was 4 years later, in 1998, when the FDA ultimately reclassified pedicle screws. ${ }^{71}$

After this reclassification, an enormous boom occurred in the industry, leading to modern-day implant systems. These systems include improvements in design related to screw and rod materials, threading, cap technology, angle preference, and reduction tools. Advances in biomechanics research have paralleled this growth, thereby providing a more objective understanding of the instrumentation's strengths and weaknesses.

\section{Cervical Fixation}

Stabilization methods for the cervical spine warrant special attention, particularly regarding methods focused on treating atlantoaxial instability and injuries. Similar to the history of fixation for thoracolumbar conditions, at- lantoaxial instability was treated with immobilization and was largely considered inoperable until the early 1900s. In 1910, Mixter and Osgood ${ }^{54}$ first described using silk sutures to fixate atlantoaxial instability with reduction accomplished via manual pressure on the pharynx and traction on the posterior arch of C1. Subsequently, Foerster ${ }^{27}$ first described attempts to achieve atlantoaxial fusion using fibular grafts in 1927. Various advances in wiring techniques for obtaining fusion followed. Gallie described the first well-established technique of a bone graft wired between the posterior arches of $\mathrm{C} 1$ and $\mathrm{C} 2$, which he presented to the American Academy of Orthopaedic Surgeons in the early 1950s (C. Tator, personal communication, 1992; Fig. 3A). Two decades later, Brooks ${ }^{13}$ attempted to improve shortcomings in the rotational restriction of the Gallie construct by using two individually compressed notched bone grafts, one in each interlaminar space (Fig. 3B). ${ }^{13}$ At our institution, the Sonntag-Dickman modified approach, ${ }^{25}$ which was first described in $1989,{ }^{24}$ used an interspinous iliac crest method similar to Gallie's, requiring sublaminar wires only under the arch of one level at C1 (Fig. 3C). ${ }^{25}$

Around the same time, Magerl ${ }^{31}$ described placement of a transarticular screw for stabilization of the C1-2 segments that did not require the dorsal elements to be intact (although the construct was often later complemented with a Sonntag-Dickman construct to improve the chances of fusion). The placement of this transarticular screw provided greater prevention of lateral bending and axial rotational movements than posterior bone constructs alone..$^{56}$ In 1994, Goel ${ }^{28}$ described using a modified plate and plate fixation of the lateral masses of $\mathrm{C} 1$ and $\mathrm{C} 2$, thereby allowing for direct reduction of $\mathrm{C} 1$ subluxation and circumventing cases in which subarticular screw placement would be precluded by aberrant vertebral artery anatomy. Harms and Melcher ${ }^{35}$ enhanced this method by using screws in the lateral masses of $\mathrm{C} 1$ and pedicles of $\mathrm{C} 2$ connected by two rods (Fig. 3D). It should also be noted that direct screw fixation techniques of odontoid fractures were developed around this same time; numerous series had been published by 1990, and the original description was credited to Böhler's 1981 publication. ${ }^{9}$

Similar techniques were adapted for cervical occipital constructs as well, with wiring techniques providing the majority of occipital fixation. In 1993, Sonntag ${ }^{72}$ described the use of a contoured Steinmann pin bent into an inverted U-shape with which occipital wires could be rigidly fixated to the cervical spine as far caudally as required, and bone graft could be harnessed for fusion (Fig. 3E). ${ }^{72}$ This procedure gave way to later techniques that used occipital plating $^{63,70}$ or condylar screws. ${ }^{78}$

In the subaxial cervical spine, multiple subaxial wiring techniques were employed, including interspinous, sublaminar, and facet techniques. The Roy-Camille plate improved on these techniques in 1983 and allowed for the absence of a dorsal boney arch by introducing lateral mass screws. ${ }^{62}$ Lateral mass screws improved fixation and allowed patients to heal without halo orthosis (Fig. 2C). Several years later, the Magerl hook-plate system ${ }^{30}$ was described, which improved upon lateral mass fixation by suggesting a slightly different screw trajectory to reduce 

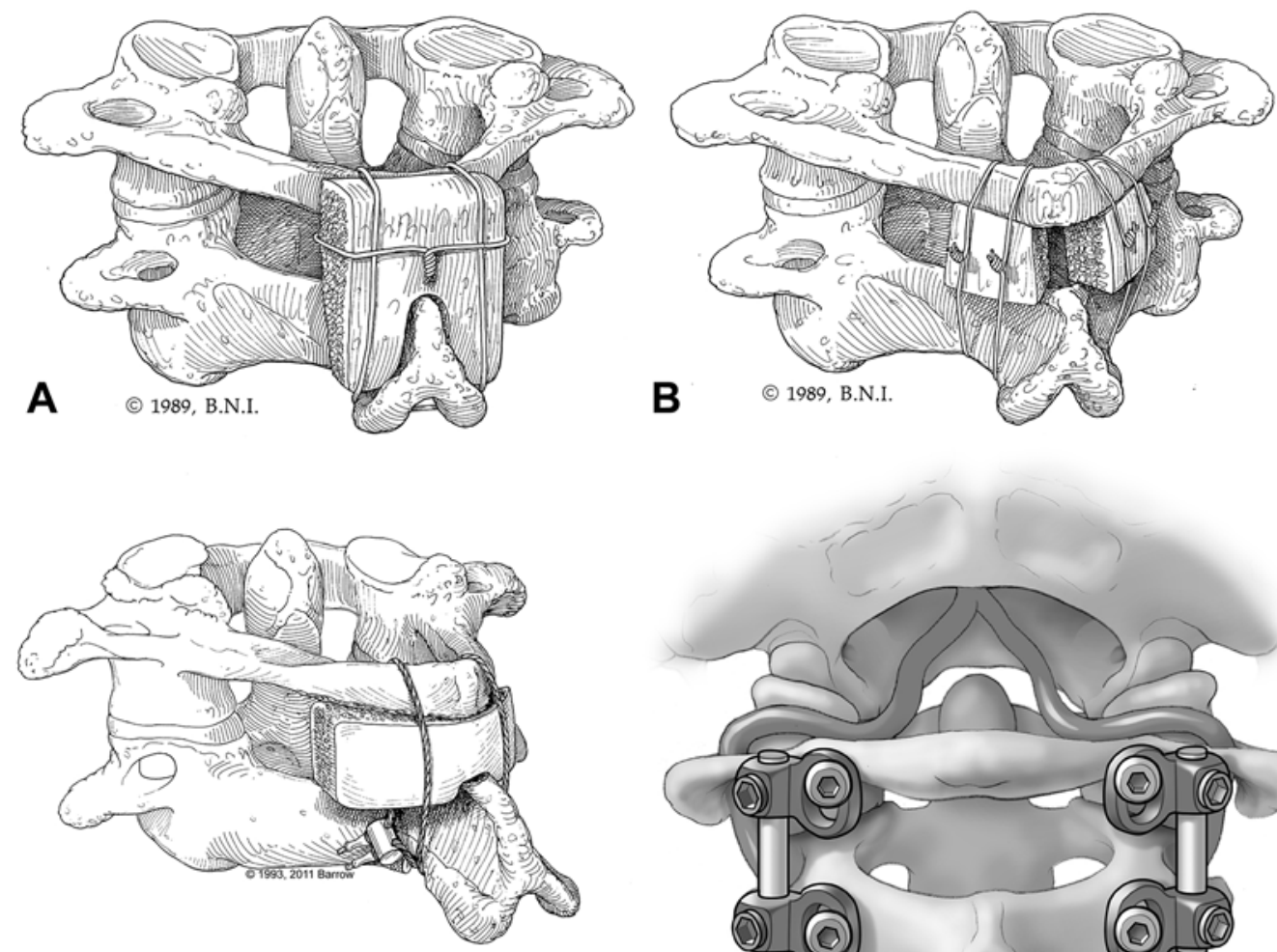

C
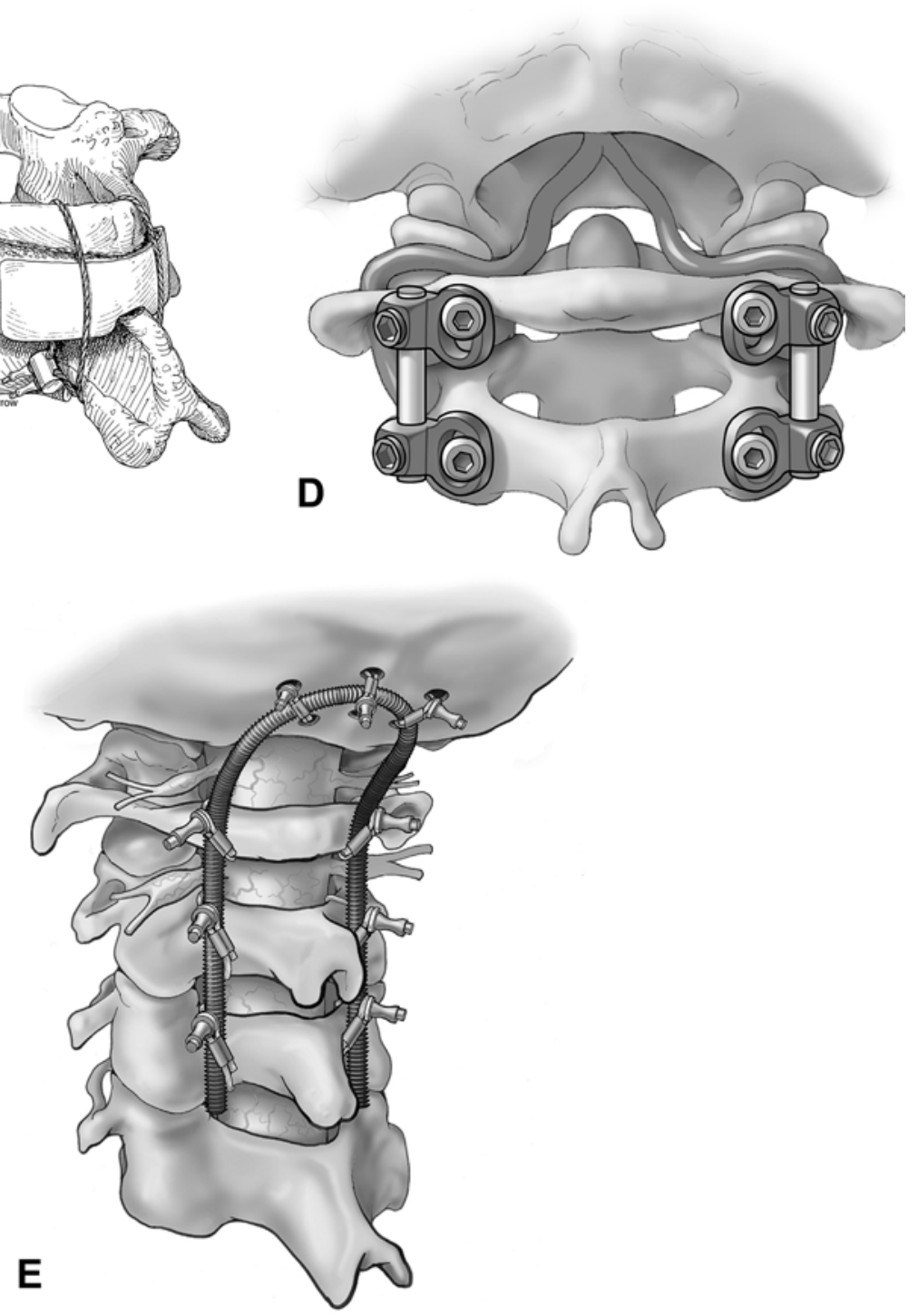

FIG. 3. Illustrations of the atlantoaxial fixation techniques described by Gallie (C. Tator, personal communication, 1992, A), Brooks (B), ${ }^{13}$ Sonntag (C), ${ }^{25}$ and Harms (D). ${ }^{35}$ Early occipital cervical fixation was performed using wire constructs attached to a U-shaped Steinmann pin (E). ${ }^{72}$ Figures $3 \mathrm{~A}-\mathrm{C}$ and $\mathrm{E}$ are used with permission from Barrow Neurological Institute, Phoenix, Arizona. Figures $3 A$ and $C$ previously appeared in Sonntag VKH, Dickman CA: Treatment of upper cervical spine injuries, in Rea GL, Miller CA (eds): Spinal Trauma: Current Evaluation and Management. Park Ridge, IL: AANS Publications, 1993, pp 25-74. Figure 3B previously appeared in Sonntag VKH, Dickman CA: Occipitocervical instrumentation, in Hitchon PW, Traynelis VC, Rengachary S (eds): Techniques in Spinal Fusion and Stabilization. New York: Thieme Medical Publishers, 1993, pp 243-272. Figure 3E previously appeared in Dickman CA, Apostolides PJ, Karahalios DG: Surgical techniques for upper cervical spine decompression and stabilization. Clin Neurosurg 44:137-160, 1997. Figure 3D is reprinted from Operative Techniques in Neurosurgery, Vol 7, Gonzalez LF, Theodore N, Dickman CA, Sonntag VKH, Occipitoatlantal and atlantoaxial dislocation, pp 16-21, 2004, with permission from Elsevier. https://www.sciencedirect.com/journal/operative-techniques-in-neurosurgery. 


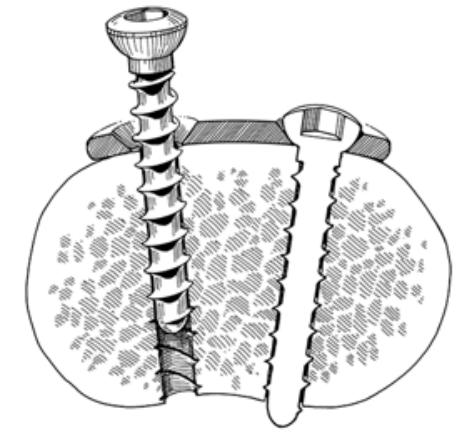

A
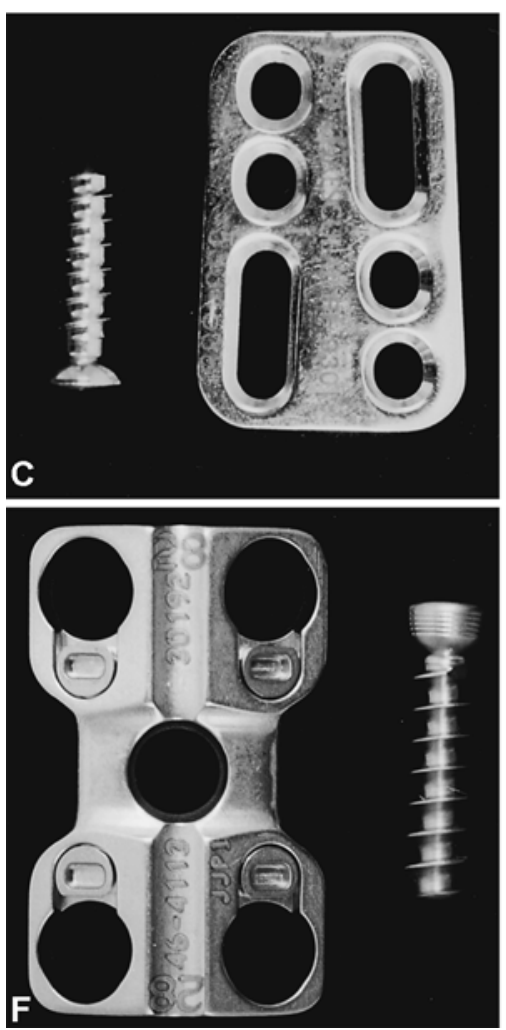
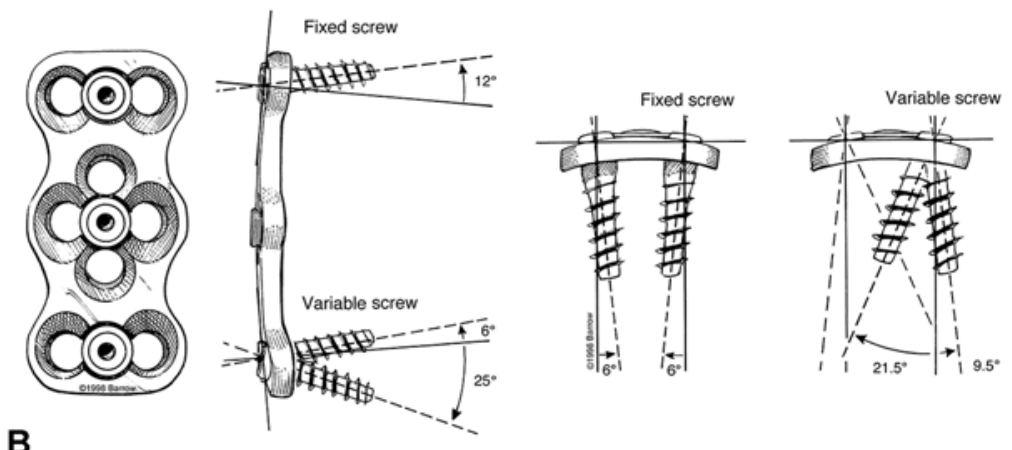

B
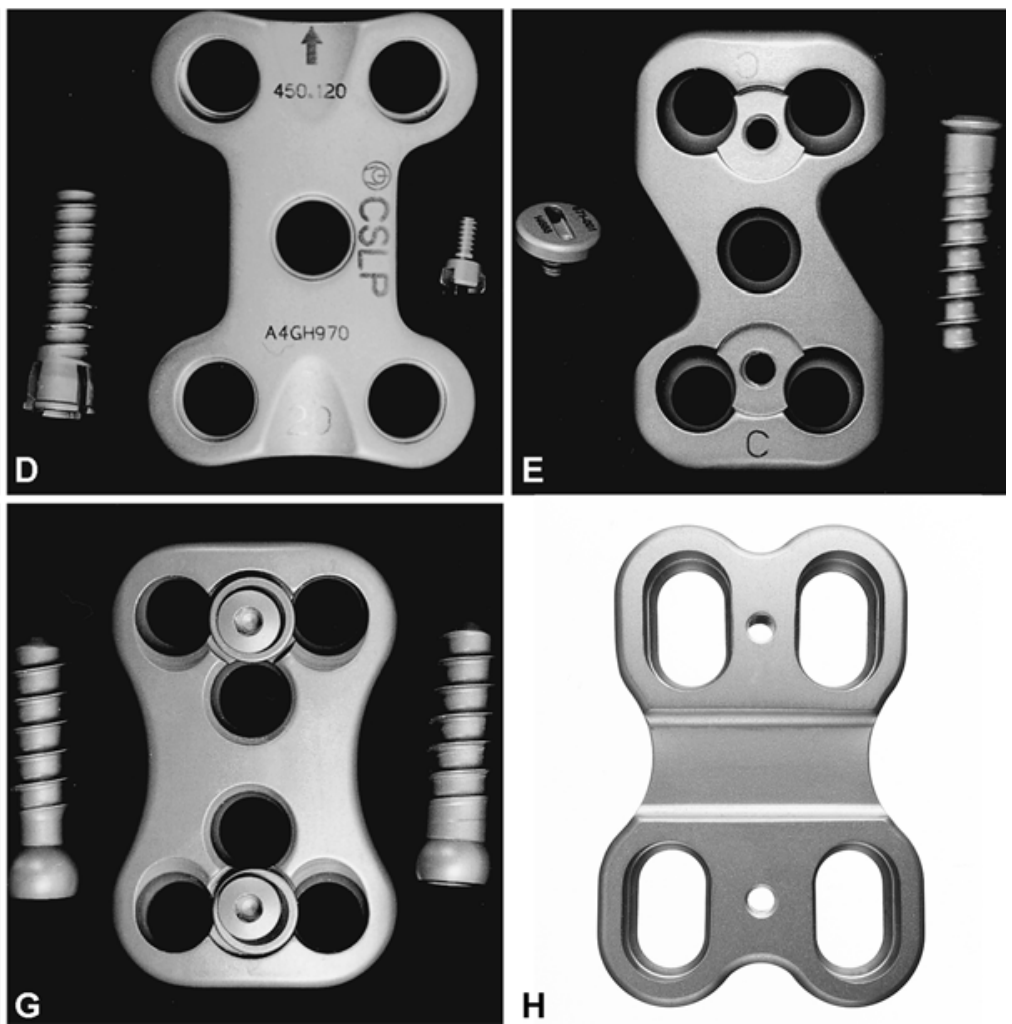

$\mathbf{H}$

FIG. 4. Early anterior cervical fixation required bicortical screw fixation (A) but improved with the development of fixed/variable and locking screws, as shown here with the Atlantis plate (B). Multiple cervical plate designs have advanced plating technology, including the Caspar (C, Aesculap), Synthes CSLP (D, DePuy Synthes), Orion (E, Medtronic Sofamor Danek), Codman (F, Johnson \& Johnson), Atlantis (G, Medtronic Sofamor Danek), and ABC Trapezoidal ${ }^{\mathrm{TM}}(\mathrm{H}$, Aesculap) plates. Figures $4 \mathrm{~A}$ and B are used with permission from Barrow Neurological Institute, Phoenix, Arizona. Figure 4A previously appeared in Dickman CA, Sonntag VKH, Marcotte PJ: Techniques of screw fixation of the cervical spine. BNI Quarterly 8:9-26, 1992. Figure 4B previously appeared in Baskin JJ, Vishteh AG, Dickman CA, Sonntag VKH: Techniques of anterior cervical plating. Operat Tech Neurosurg 1:90-102, 1998. Figures 4C-G are reprinted from Operative Techniques in Neurosurgery, Vol 1, Baskin JJ, Vishteh AG, Dickman CA, Sonntag VKH, Techniques of anterior cervical plating, pp 90-102, 1998, with permission from Elsevier. https://www.sciencedirect. $\mathrm{com} /$ journal/operative-techniques-in-neurosurgery. Figure $4 \mathrm{H}$ is used with permission from Aesculap.

the risk of neural and vascular injury. Continued improvements in these screw techniques ${ }^{3,4}$ and screw-rod fixation systems then followed. ${ }^{43}$

Early attempts at anterior cervical fusion date back to the 1950 s, with the first description by Bailey and Badgley in $1960^{7}$ and technical improvements in the noninstrumented technique by Smith and Robinson ${ }^{68}$ and Cloward..$^{17,18}$ Anterior cervical plating (ACP) transformed the field of cervical fusion, and an entire article focused on this topic alone is warranted..$^{34,55}$ The first reported use occurred in 1970 by Orozco and Llovet, ${ }^{59}$ and Caspar popularized its use in the 1980s. ${ }^{16}$ These early ACPs were unrestricted back-out plates and required bicortical screw purchase, a stipulation that increased the risk of spinal cord injury and screw pullout (Fig. 4A). In response to each ACP shortcoming, a wave of designs emerged, with the refinement of constrained and semi-constrained screws, screw locking mechanisms, and hybrid systems allowing for angled or variable trajectories, grooves for drill taps, and prebent lordotic curvature (Fig. 4B-H). Trailing 

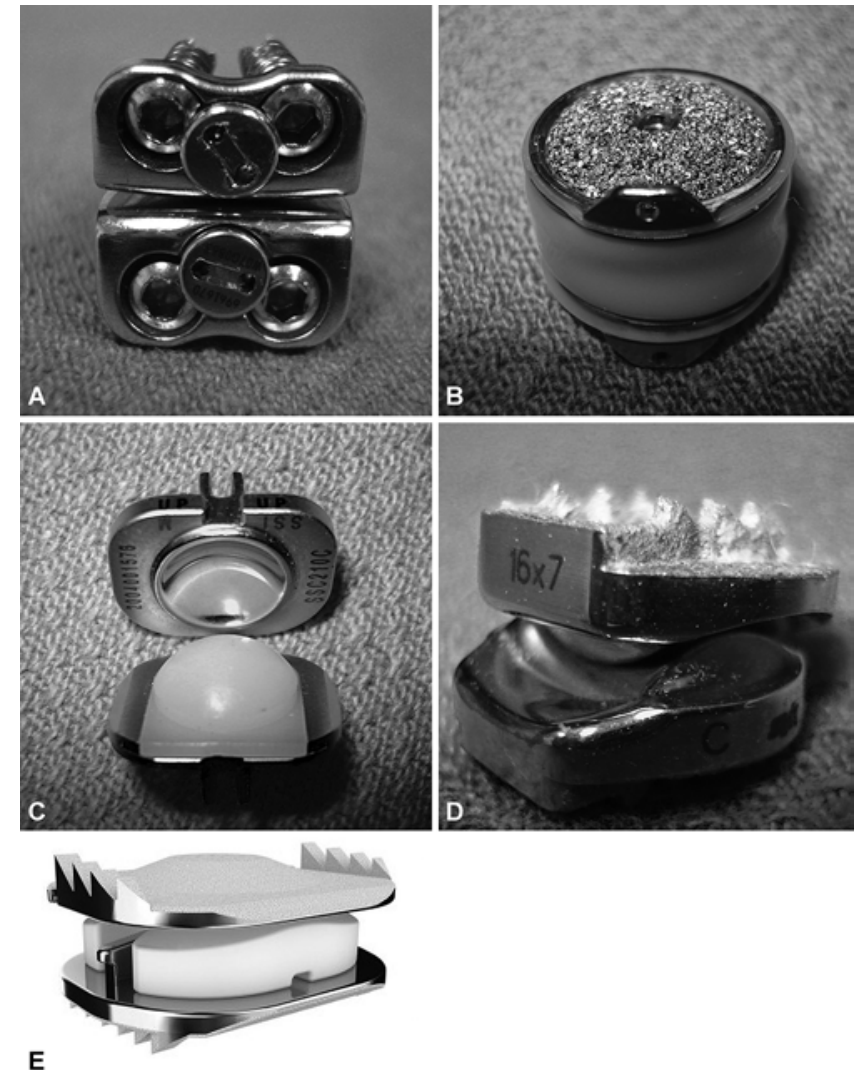

FIG. 5. Cervical arthroplasty designs: Prestige (A, Medtronic Sofamor Danek), Bryan (B, Medtronic Sofamor Danek), ProDisc-C (C, DePuy Synthes), CerviCore (D, Stryker Spine), and Mobi-C (E, Zimmer Biomet). Figures 5A-D are reproduced from Baaj et al: Neurosurg Focus 27(3):E10, 2009. Published with permission. Figure $5 E$ is used with permission from Zimmer Biomet.

behind ACP technology has been that of the interbody design, with the emergence of polyetheretherketone, metal alloys, and, most recently, nanotextured surfaces intended to allow graft-bone interfacing.

Cervical arthroplasty, too, has found its unique evolution more recently. While Fernström is credited with placing the first artificial cervical device in $1966^{26}$-a stainless steel ball-bearing prosthesis used to treat headaches and cervicobrachialgia-the device suffered from failures in design. Repeat attempts at cervical arthroplasty were made by Cummins in 1989 in Bristol, UK, again with discouraging complications of hardware failure and persistent dysphagia.77 Widespread use was ignited after the completion of successful randomized trials of the redesigned Cummins-Bristol disc, now called the "Prestige Disc," and a competing design called the "ProDisc-C," leading to FDA approval of both devices in 2007.6 Since that time, additional designs and material advancements have been made to the technology alongside additive experimental data supporting the viability and value of motion preservation in appropriate clinical settings (Fig. 5).

\section{Surgical Technology in Spine Surgery}

Arguably the largest driver of neurosurgical advance- ment during the past century has been related to imaging improvements, and this too applies to spinal disease. Early studies of myelography building off the foundational roentgenography date back to the 1920 s and 1930s with the injection of lipid-based contrast agents. ${ }^{67,79}$ After the invention of computed tomography (CT) in 1972 and magnetic resonance imaging in 1974, enhanced evaluation of the spine followed.

While these advances in imaging science applied to both diagnosis and evaluation of surgical disorders, they also led directly to the adoption of image guidance for intraoperative use. One of the earliest reported studies in spine surgery demonstrating the use of fluoroscopic guidance was by Selman, Spetzler, and Brown ${ }^{66}$ in 1981, in which they described using fluoroscopy to assess the extent of resection during 4 cases of transoral odontoidectomy. The similar use of biplanar fluoroscopy for odontoid screw placement followed. ${ }^{10}$ In 1996, Odgers et al.$^{58}$ first published their study of pedicle screws placed using intraoperative lateral fluoroscopy, thereby creating the first discussions of screw navigation.

The introduction of frameless stereotaxy using surface reference markers was shown to be beneficial for intracranial surgery, but the technique was first applied in 1995 by Kalfas et al. ${ }^{44}$ for the use of pedicle screw fixation. In this early application, a preoperative CT study was registered to spinal anatomy interfaced with a sonic digitizer device. This technique was followed in the 2000s by intraoperative CT navigation, which improved on limitations of preoperative CT guidance. ${ }^{32,42}$ Adaptations of the navigation software, instrumentation, reference arrays, and intraoperative CT scanners continue to result in improvements in spine surgery. As a result, surgeons have been able to achieve extremely high pedicle screw accuracy rates using modern navigation.

In 2000, the FDA cleared the da Vinci surgical robot (Intuitive Surgical) for general laparoscopic surgery applications. This approval paved the way for the first robotic spinal navigation system, SpineAssist (Mazor Robotics Ltd.), in 2004. Since then, SpineAssist has been replaced by its successors, the Renaissance Guidance System (Mazor Robotics) and the Mazor X (Medtronic), as well as its competitor the ExcelsiusGPS (Fig. 6A; Globus Medical Inc.). While the field of surgical robotics appears to be in its infancy, studies continue to demonstrate promise and suggest that robotics in spinal navigation will continue to play a key role in the future. ${ }^{75}$

\section{Minimally Invasive Spine Surgery}

Attempts to minimize the patient morbidity associated with surgery of the cervical, thoracic, and lumbar spine have been extensive. Early attempts to treat lumbar disc herniation centered on methods that removed central disc content, reduced intradiscal pressure, and helped decrease neural compression. Chemonucleolysis using chymopapain, first used in 1964 by Smith, ${ }^{69}$ and percutaneous laserassisted discectomy, first used in 1984 by Ascher and Heppner, ${ }^{5}$ are two examples of such methods. After reducing neural compression, direct visualization of the disc was then performed, with Hijikata ${ }^{41}$ first describing percutane- 

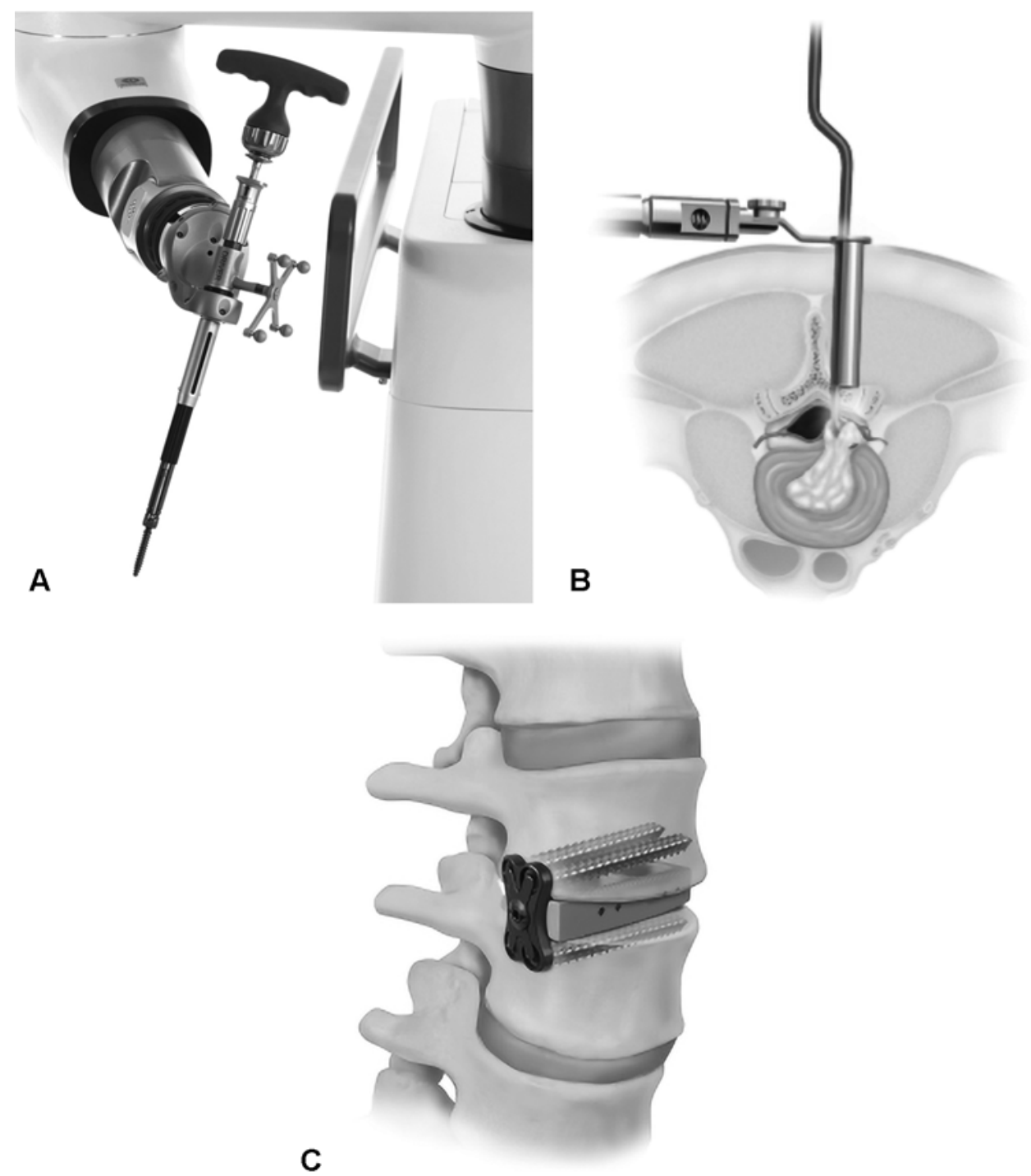

FIG. 6. Minimally invasive spinal technology: robotic ExcelsiusGPS (A, Globus Medical Inc.) surgical arm for placing guided pedicle screws, METRx tube (B, Medtronic Sofamor Danek) for minimally invasive tubular microdiscectomy, and lateral interbody arthrodesis (C). Figure $6 \mathrm{~A}$ is used with permission from Globus Medical. Figure $6 \mathrm{~B}$ is used with permission from Medtronic. Figure $6 \mathrm{C}$ is used with permission from Zimmer Biomet.

ous nucleotomy through a posterolateral approach. Kambin and Gellman ${ }^{45}$ followed suit by performing fluoroscopically guided percutaneous discectomies in 1983.

However, these techniques failed to address sequestered and migrated disc fragments. This issue led to directly visualized discectomies performed under the microscope, as described by Yasargil ${ }^{81}$ and Caspar. ${ }^{15}$ Thus, a microendoscopic tubular system was introduced in 1997 (ultimately improved upon to form the METRx system [Medtronic Sofamor Danek; Fig. 6B]) and became popular for performing discectomies, foraminotomies, and laminectomies. ${ }^{61}$ Building off Scoville's technique (first described in 1976) ${ }^{65}$ of posterior cervical discectomies, Adamson used the same tubular techniques to perform microendoscopic cervical foraminotomies. ${ }^{1}$ Similarly, in 2005, Foley's group combined early descriptions of the transforaminal interbody placement by Harms and Rolinger in $1982^{36}$ and percutaneous pedicle screw fixation by Wiesner et al. in $2000^{80}$ with microendoscopic lumbar techniques to derive the minimally invasive transforaminal interbody approach, as described by Schwender et al. ${ }^{64}$

Minimally invasive anterior and anterolateral approaches to the thoracic and lumbar spine followed their unique histories. The earliest reports of anterior interbody fusion date back to 1933, when Burns first treated patients with spondylolisthesis. ${ }^{14}$ With the growing prominence of general, urological, and gynecological laparoscopic surgical applications in the 1980s, Obenchain ${ }^{57}$ described the first anterior lumbar discectomy using laparoscopy in 1991. At roughly the same time, Fessler first described the endoscopic approach to the retroperitoneal lumbar spine in 1992 (and his approach to fusion via this method in 1997: "Endoscopically assisted retroperitoneal fusion," presented at the AANS Annual Meeting held in Denver, 
$\mathrm{CO}$ ), while video-assisted thoracoscopic surgery was initially reported by Mack and colleagues in $1993 .{ }^{49}$ In the years that followed, mini-open retractor-based approaches took over following Mayer's description of a minimally invasive oblique retroperitoneal access to the lumbar spine in $1997^{52}$ and Ozgur and colleagues' description of the lateral transpsoas technique in 2006 (Fig. 6C) ${ }^{60}$ Combined with advances in navigation and robotics, novel biomaterials, and advanced biologics, the application of these techniques has broadened applications to increasingly complex pathologies, including spinal deformity and scoliosis; thoracic disc disease; and corpectomies for trauma, tumor, and infectious etiologies.

\section{Surgical Education and Fellowship}

Neurosurgical involvement in spinal disease dates back to Cushing's first attempt at intramedullary spinal tumor resection in 1905. ${ }^{21}$ Major contributions by neurosurgeons, such as Stockey, Semmes, Murphy, Spurling, and Scoville, in the 1930s, 1940s, and 1950s helped to drive the treatment of spinal disease forward. However, neurosurgical participation in spinal fusion remained limited until the late 1980s, when a growing number of neurosurgeons started to take on the early cervical fixation techniques described above. But only one neurosurgical spine fellowship, Sandy Larson's in Wisconsin, existed at that time. That changed when the Accreditation Council for Graduate Medical Education first started to recognize orthopedic spine fellowships for accreditation in the late 1980s. In response to the fear that neurosurgical education would lose its role in spine surgery and training, a Spine Task Force, led by David Kelly, was put into place to develop guidelines for the spinal surgery training of neurosurgical residents and fellows. The task force emphasized that neurosurgeons not only participate in cervical fixation but also have full rights to thoracic and lumbosacral instrumentation. Initially, this was met with severe retaliation from the orthopedic surgeons. However, as neurosurgical and orthopedic communities banded together at that time to engage in the aforementioned pedicle screw battle, the struggle for turf in spine surgery resolved slowly over the ensuing years, and the relationship between the two specialties has continued to improve since. In the early 2000 s, neurosurgical spine fellowships became accredited by the Society of Neurological Surgeons under CAST (Committee on Advanced Subspecialty Training) and continue to be recognized as some of the best in the field.

With the expansion of neurosurgical involvement in spine surgery, an explosion of research in the field followed. Early neurosurgical conferences and journals included minimal content on spinal conditions; however, this situation steadily changed throughout the late 1990s. In 1999, the Journal of Neurosurgery: Spine first appeared as a quarterly publication. Likewise, over the years, Neurosurgery has published many of the major consensus guidelines on spinal care. The AANS/CNS Section on Disorders of the Spine and Peripheral Nerves is regularly attended by both neurosurgeons and orthopedic surgeons, reflecting the collegiality of the two disciplines. Cross-training of many neurosurgical fellows also continues to grow as the understanding and treatment of spinal deformity, particularly in adults, continues to expand. The inclusion in the general neurosurgical residency curriculum of spinopelvic parameters, sagittal alignment, and scoliosis reflects these changes as well. Moreover, it is now estimated that, of all neurosurgical operations, $77 \%$ are performed for spinal cases, and this percentage is growing as of $2013 .{ }^{19}$

\section{Conclusions}

The field of spine surgery has undergone one of the greatest transformations in medicine over the past 100 years. In that period, the most significant advancement has come with the evolution of spinal instrumentation and fusion in the past 3 decades. In this article, we have been able to capture only certain components of many monumental milestones, each of which likely required the dedication of many unnamed surgeons, scientists, engineers, and entrepreneurs. Both neurosurgical and orthopedic contributions have been tremendous, with continued daily innovation, particularly in the areas of navigation, robotics, materials science, and spinal biomechanics. These contributions have allowed for safer, more efficacious, and more efficient methods of treatment, improving outcomes and quality of life for patients. Looking at the history of spine surgery and its incredible recent journey provides excitement for continued progress in the future.

\section{Acknowledgments}

We thank the staff of the Neuroscience Publications office at Barrow Neurological Institute for assistance with manuscript preparation.

\section{References}

1. Adamson TE: Microendoscopic posterior cervical laminoforaminotomy for unilateral radiculopathy: results of a new technique in 100 cases. J Neurosurg 95 (1 Suppl):51-57, 2001

2. Albee F: Transplantation of a portion of the tibia into the spine for Pott's disease: a preliminary report. JAMA 57:885, 1911

3. An HS, Coppes MA: Posterior cervical fixation for fracture and degenerative disc disease. Clin Orthop Relat Res (335):101-111, 1997

4. Anderson PA, Henley MB, Grady MS, Montesano PX, Winn HR: Posterior cervical arthrodesis with AO reconstruction plates and bone graft. Spine (Phila Pa 1976) 16 (3 Suppl):S72-S79, 1991

5. Ascher PW, Heppner F: CO2-Laser in neurosurgery. Neurosurg Rev 7:123-133, 1984

6. Baaj AA, Uribe JS, Vale FL, Preul MC, Crawford NR: History of cervical disc arthroplasty. Neurosurg Focus 27(3):E10, 2009

7. Bailey RW, Badgley CE: Stabilization of the cervical spine by anterior fusion. J Bone Joint Surg Am 42-A:565-594, 1960

8. Bick EM: An essay on the history of spine fusion operations. Clin Orthop Relat Res 35:9-15, 1964

9. Böhler J: Schraubenosteosynthese von Frakturen des Dens axis. Unfallchirurgie 84:221-223, 1981

10. Borne GM, Bedou GL, Pinaudeau M, Cristino G, Hussein A: Odontoid process fracture osteosynthesis with a direct screw fixation technique in nine consecutive cases. J Neurosurg 68:223-226, 1988 
11. Boucher HH: A method of spinal fusion. J Bone Joint Surg Br 41-B:248-259, 1959

12. Briggs H, Milligan PR: Chip fusion of the low back following exploration of the spinal canal. J Bone Joint Surg Am 26:125-130, 1944

13. Brooks AL, Jenkins EB: Atlanto-axial arthrodesis by the wedge compression method. J Bone Joint Surg Am 60:279284, 1978

14. Burns B: An operation for spondylolisthesis. Lancet 221:1233, 1933

15. Caspar W: A new surgical procedure for lumbar disc herniation causing less tissue damage through a microsurgical approach, in Wüllenweber M, Brock J, Hamer M, et al (eds): Lumbar Disc Adult Hydrocephalus. Berlin: Springer, 1977, pp 74-80

16. Caspar W, Barbier DD, Klara PM: Anterior cervical fusion and Caspar plate stabilization for cervical trauma. Neurosurgery 25:491-502, 1989

17. Cloward RB: The anterior approach for removal of ruptured cervical disks. J Neurosurg 15:602-617, 1958

18. Cloward RB: Treatment of acute fractures and fracturedislocations of the cervical spine by vertebral-body fusion. A report of eleven cases. J Neurosurg 18:201-209, 1961

19. Cote DJ, Karhade AV, Larsen AM, Burke WT, Castlen JP, Smith TR: United States neurosurgery annual case type and complication trends between 2006 and 2013: an American College of Surgeons National Surgical Quality Improvement Program analysis. J Clin Neurosci 31:106-111, 2016

20. Cotrel Y, Dubousset J, Guillaumat M: New universal instrumentation in spinal surgery. Clin Orthop Relat Res 227:1023, 1988

21. Cushing H: The special field of neurological surgery. Bull Johns Hopkins Hosp 15:77-87, 1905

22. Dick W: The "fixateur interne" as a versatile implant for spine surgery. Spine (Phila Pa 1976) 12:882-900, 1987

23. Dick W, Kluger P, Magerl F, Woersdörfer O, Zäch G: A new device for internal fixation of thoracolumbar and lumbar spine fractures: the 'fixateur interne'. Paraplegia 23:225232,1985

24. Dickman CA, Hadley MN, Browner C, Sonntag VK: Neurosurgical management of acute atlas-axis combination fractures. A review of 25 cases. J Neurosurg 70:45-49, 1989

25. Dickman CA, Sonntag VK, Papadopoulos SM, Hadley MN: The interspinous method of posterior atlantoaxial arthrodesis. J Neurosurg 74:190-198, 1991

26. Fernström U: Arthroplasty with intercorporal endoprothesis in herniated disc and in painful disc. Acta Chir Scand Suppl 357:154-159, 1966

27. Foerster O: Die Leitungsbahnen des Schmerzgefühls und die chirurgische Behandlung der Schmerzzustände. Berlin: Urban \& Schwarzenburg, 1927

28. Goel A, Laheri V: Plate and screw fixation for atlanto-axial subluxation. Acta Neurochir (Wien) 129:47-53, 1994

29. Goodrich JT: History of spine surgery in the ancient and medieval worlds. Neurosurg Focus 16(1):E2, 2004

30. Grob D, Magerl F: [Dorsal spondylodesis of the cervical spine using a hooked plate.] Orthopade 16:55-61, 1987 (German)

31. Grob D, Magerl F: [Surgical stabilization of $\mathrm{C} 1$ and $\mathrm{C} 2$ fractures.] Orthopade 16:46-54, 1987 (German)

32. Haberland N, Ebmeier K, Grunewald JP, Hliscs R, Kalff RL: Incorporation of intraoperative computerized tomography in a newly developed spinal navigation technique. Comput Aided Surg 5:18-27, 2000

33. Hadra B: Wiring the spinous processes in Pott's disease. J Bone Joint Surg Am 4:206-210, 1891

34. Haid RW, Foley KT, Rodts GE, Barnes B: The Cervical Spine Study Group anterior cervical plate nomenclature. Neurosurg Focus 12(1):E15, 2002
35. Harms J, Melcher RP: Posterior C1-C2 fusion with polyaxial screw and rod fixation. Spine (Phila Pa 1976) 26:2467-2471, 2001

36. Harms J, Rolinger H: [A one-stager procedure in operative treatment of spondylolistheses: dorsal traction-reposition and anterior fusion (author's transl).] Z Orthop Ihre Grenzgeb 120:343-347, 1982 (German)

37. Harrington PR: The history and development of Harrington instrumentation. Clin Orthop Relat Res (93):110-112, 1973

38. Harrington PR, Dickson JH: An eleven-year clinical investigation of Harrington instrumentation. A preliminary report on 578 cases. Clin Orthop Relat Res (93):113-130, 1973

39. Harrington PR, Tullos HS: Reduction of severe spondylolisthesis in children. South Med J 62:1-7, 1969

40. Hibbs RA: An operation for progressive spinal deformities: a preliminary report of three cases from the service of the orthopaedic hospital. 1911. Clin Orthop Relat Res 460:17-20, 2007

41. Hijikata S: Percutaneous nucleotomy. A new concept technique and 12 years' experience. Clin Orthop Relat Res (238):9-23, 1989

42. Hott JS, Papadopoulos SM, Theodore N, Dickman CA, Sonntag VK: Intraoperative Iso-C C-arm navigation in cervical spinal surgery: review of the first 52 cases. Spine (Phila Pa 1976) 29:2856-2860, 2004

43. Jeanneret B: Posterior rod system of the cervical spine: a new implant allowing optimal screw insertion. Eur Spine $\mathbf{J}$ $\mathbf{5 : 3 5 0 - 3 5 6 , 1 9 9 6}$

44. Kalfas IH, Kormos DW, Murphy MA, McKenzie RL, Barnett GH, Bell GR, et al: Application of frameless stereotaxy to pedicle screw fixation of the spine. J Neurosurg 83:641-647, 1995

45. Kambin P, Gellman H: percutaneous lateral discectomy of the lumbar spine a preliminary report. Clin Orthop Relat Res 174:127-132, 1983

46. King D: Internal fixation for lumbosacral fusion. J Bone Joint Surg Am 30A:560-565, 1948

47. Luque ER: Interpeduncular segmental fixation. Clin Orthop Relat Res (203):54-57, 1986

48. Macewen W: Pyogenic Disease of the Brain and Spinal Cord; Meningitis, Abscess of the Brain, Infective Sinus Thrombosis. Glasgow: Maclehose, 1893

49. Mack MJ, Regan JJ, Bobechko WP, Acuff TE: Application of thoracoscopy for diseases of the spine. Ann Thorac Surg 56:736-738, 1993

50. Magerl FP: Stabilization of the lower thoracic and lumbar spine with external skeletal fixation. Clin Orthop Relat Res (189):125-141, 1984

51. Marketos SG, Skiadas P: Hippocrates. The father of spine surgery. Spine (Phila Pa 1976) 24:1381-1387, 1999

52. Mayer HM: A new microsurgical technique for minimally invasive anterior lumbar interbody fusion. Spine (Phila Pa 1976) 22:691-700, 1997

53. Menard V: Traitement de la paraplegie du mal de Pott par drainage lateral: Costotransversektomie. Rev Orthop Paris 6:134-146, 1895

54. Mixter SJ, Osgood RB: IV. Traumatic lesions of the atlas and axis. Ann Surg 51:193-207, 1910

55. Moftakhar R, Trost GR: Anterior cervical plates: a historical perspective. Neurosurg Focus 16(1):E8, 2004

56. Naderi S, Crawford NR, Song GS, Sonntag VK, Dickman $\mathrm{CA}$ : Biomechanical comparison of $\mathrm{C} 1-\mathrm{C} 2$ posterior fixations. Cable, graft, and screw combinations. Spine (Phila Pa 1976) 23:1946-1956, 1998

57. Obenchain TG: Laparoscopic lumbar discectomy: case report. J Laparoendosc Surg 1:145-149, 1991

58. Odgers CJ IV, Vaccaro AR, Pollack ME, Cotler JM: Accuracy of pedicle screw placement with the assistance of lateral plain radiography. J Spinal Disord 9:334-338, 1996 
59. Orozco D, Llovet T: Osteosintesis en las fracturas de raquis cervical. Nota de tecnica. Rev Ortop Traumatol Ed Lat Am 14:285-288, 1970

60. Ozgur BM, Aryan HE, Pimenta L, Taylor WR: Extreme Lateral Interbody Fusion (XLIF): a novel surgical technique for anterior lumbar interbody fusion. Spine J 6:435-443, 2006

61. Perez-Cruet MJ, Foley KT, Isaacs RE, Rice-Wyllie L, Wellington R, Smith MM, et al: Microendoscopic lumbar discectomy: technical note. Neurosurgery 51 (5 Suppl):S129S136, 2002

62. Roy-Camille R, Saillant G, Judet T, Mammoudy P: [Recent injuries of the last 5 cervical vertebrae in the adult (with and without neurologic complications).] Sem Hop 59:1479-1488, 1983 (French)

63. Sasso RC, Jeanneret B, Fischer K, Magerl F: Occipitocervical fusion with posterior plate and screw instrumentation. A long-term follow-up study. Spine (Phila Pa 1976) 19:23642368, 1994

64. Schwender JD, Holly LT, Rouben DP, Foley KT: Minimally invasive transforaminal lumbar interbody fusion (TLIF): technical feasibility and initial results. J Spinal Disord Tech 18 (Suppl):S1-S6, 2005

65. Scoville WB, Dohrmann GJ, Corkill G: Late results of cervical disc surgery. J Neurosurg 45:203-210, 1976

66. Selman WR, Spetzler RF, Brown R: The use of intraoperative fluoroscopy and spinal cord monitoring for transoral microsurgical odontoid resection. Clin Orthop Relat Res (154):51-56, 1981

67. Semmes RE: Diagnosis of ruptured intervertebral disc without contrast myelography and comment upon recent experience with modified hemilaminectomy for their removal. Yale J Biol Med 11:433-435, 1939

68. Smith GW, Robinson RA: The treatment of certain cervicalspine disorders by anterior removal of the intervertebral disc and interbody fusion. J Bone Joint Surg Am 40-A:607-624, 1958

69. Smith L: Enzyme dissolution of the nucleus pulposus in humans. JAMA 187:137-140, 1964

70. Smith MD, Anderson P, Grady MS: Occipitocervical arthrodesis using contoured plate fixation. An early report on a versatile fixation technique. Spine (Phila Pa 1976) 18:19841990, 1993

71. Sonntag VK: The development of spinal neurosurgery: a historical perspective. Neurosurgery 60:587-588, 2007

72. Sonntag VK, Dickman CA: Craniocervical stabilization. Clin Neurosurg 40:243-272, 1993

73. Steffee AD, Biscup RS, Sitkowski DJ: Segmental spine plates with pedicle screw fixation. A new internal fixation device for disorders of the lumbar and thoracolumbar spine. Clin Orthop Relat Res (203):45-53, 1986
74. Tan TC, Black PM: Sir Victor Horsley (1857-1916): pioneer of neurological surgery. Neurosurgery 50:607-612, 2002

75. Theodore N, Ahmed A: The history of robotics in spine surgery. Spine (Phila Pa 1976) 43(7 Suppl):S23, 2018

76. Tourney J: Internal fixation in fusion of the lumbosacral joint. Lahey Clin Bull 3:188-191, 1943

77. Traynelis VC: Spinal arthroplasty. Neurosurg Focus 13(2):E10, 2002

78. Uribe JS, Ramos E, Baaj A, Youssef AS, Vale FL: Occipital cervical stabilization using occipital condyles for cranial fixation: technical case report. Neurosurgery 65:E1216-E1217, 2009

79. Whitcomb BB, Wyatt GM: Technique for Pantopaque myelography. J Neurosurg 3:95-99, 1946

80. Wiesner L, Kothe R, Schulitz KP, Rüther W: Clinical evaluation and computed tomography scan analysis of screw tracts after percutaneous insertion of pedicle screws in the lumbar spine. Spine (Phila Pa 1976) 25:615-621, 2000

81. Yasargil MG: Microsurgical operation for herniated disc, in Wüllenweber R, Brock M, Hamer J, et al (eds): Lumbar Disc Adult Hydrocephalus. Berlin: Springer-Verlag, 1977, p 81

82. Yuan HA, Garfin SR, Dickman CA, Mardjetko SM: A historical cohort study of pedicle screw fixation in thoracic, lumbar, and sacral spinal fusions. Spine (Phila Pa 1976) 19 (20 Suppl):2279S-2296S, 1994

83. Zindrick MR, Wiltse LL, Widell EH, Thomas JC, Holland WR, Field BT, et al: A biomechanical study of intrapeduncular screw fixation in the lumbosacral spine. Clin Orthop Relat Res (203):99-112, 1986

\section{Disclosures}

Dr. Sonntag receives royalties from Medtronic and Danali; Dr. Chang receives royalties from and is a consultant for Globus and Zimmer.

\section{Author Contributions}

Conception and design: Sonntag. Acquisition of data: Sonntag, Walker. Analysis and interpretation of data: Sonntag, Walker. Drafting the article: Walker. Critically revising the article: Sonntag, Kakarla, Chang. Reviewed submitted version of manuscript: all authors. Study supervision: Sonntag.

\section{Correspondence}

Volker K. H. Sonntag: c/o Neuroscience Publications, Barrow Neurological Institute, St. Joseph's Hospital and Medical Center, Phoenix, AZ.neuropub@barrowneuro.org. 